Tropical Journal of Pharmaceutical Research October 2020; 19 (10): 2137-2146

ISSN: $1596-5996$ (print); 1596-9827 (electronic) (C) Pharmacotherapy Group, Faculty of Pharmacy, University of Benin, Benin City, 300001 Nigeria.

\title{
Effect of extracts from selected Kenyan plants on traits of metabolic syndrome in Wistar rats fed a high-fat high- fructose diet
}

\author{
Beatrice $\mathbf{N}$ Kiage-Mokua ${ }^{1,2}$, Michael de Vrese ${ }^{1 *}$, Ina Kraus-Stojanowic ${ }^{1}$, \\ Annegret Nielsen ${ }^{1}$, Patrick Kareru², Gaston Kenji ${ }^{2}$, Christine Onyango², Nils \\ Roos $^{1}$, Darab Ghadimi ${ }^{1 *}$, Jürgen Schrezenmeir ${ }^{1,3}$ \\ ${ }^{1}$ Formerly, Max Rubner-Institut, Federal Research Institute of Nutrition and Food, Department of Microbiology and \\ Biotechnology; Kiel, Germany, ${ }^{2}$ Jomo Kenyatta University of Agriculture \& Technology, Department of Food Science and \\ Technology, Nairobi, Kenya, ${ }^{3}$ Clinical Research Center, Kiel Innovation and Technology Center, Kiel, Germany
}

*For correspondence: Email: darab.ghadimi@mri.bund.de; Tel: +49-431-6092512

\begin{abstract}
Purpose: To examine the potential of extracts from selected herbs used in African traditional medicine in diabetes patients, and to determine their effect on traits of metabolic syndrome in rats fed a high-fat and high-fructose diet.

Methods: Ethanol and aqueous extracts were prepared from Mangifera indica (MI), Lonchocarpus eriocalyx (LE), Urtica massaica (UM), Schkuhria pinnata (SP) and Launaea cornuta (LC). Ethanol extracts (1:100 dilution) were examined for inhibition of pancreatic lipase and $\alpha$-glucosidase activity in vitro. Furthermore, aqueous extracts were administered for 74 days to male Wistar rats fed a high-fat and high-fructose diet to assess their effect on traits of metabolic syndrome.

Results: Ethanol extracts showed at least $30 \%$ inhibition of pancreatic lipase in vitro but no effect on $\alpha$ glucosidase activity. Administration of the aqueous extracts caused significant reduction in liver triglycerides (except for LE). Muscle triglycerides and fat were also reduced, with the most pronounced effect elicited by LE. Urinary glucose excretion and plasma triglycerides, but not hyperinsulinemia and insulin resistance, were reduced by UM compared to control.

Conclusion: This exploratory study indicates that UM may be considered a candidate for the prevention and management of type 2 diabetes.
\end{abstract}

Keywords: Kenyan traditional medicine, High-fat diet, High fructose, Insulin resistance, Triglycerides, Diabetes, Liver steatosis

\begin{abstract}
This is an Open Access article that uses a funding model which does not charge readers or their institutions for access and distributed under the terms of the Creative Commons Attribution License (http://creativecommons.org/licenses/by/4.0) and the Budapest Open Access Initiative (http://www.budapestopenaccessinitiative.org/read), which permit unrestricted use, distribution, and reproduction in any medium, provided the original work is properly credited.

Tropical Journal of Pharmaceutical Research is indexed by Science Citation Index (SciSearch), Scopus International Pharmaceutical Abstract, Chemical Abstracts, Embase, Index Copernicus, EBSCO, African Index Medicus, JournalSeek, Journal Citation Reports/Science Edition, Directory of Open Access Journals (DOAJ), African Journal Online, Bioline International, Open-J-Gate and Pharmacy Abstracts
\end{abstract}

\section{INTRODUCTION}

The prevalence of diabetes is increasing globally [1]. Type 2 diabetes (T2DM) occurs 5 to 10 times more frequently in obese adults than in adults with normal weight. Obesity and diabetes increase plasma free fatty acids (FFAs) $[2,3]$ and induce other lipid disorders, thereby increasing the risks of cardiovascular disease, a common problem in patients with diabetes [4]. 
The main cause of obesity is excess consumption of calories, especially the combination of fructose and fats, together with low physical activity [5]. Likewise, rodents fed high fat and fructose diets develop visceral obesity, dyslipidemia, hyperglycemia, hyperinsulinemia, and hepatic steatosis, which are characteristics of human obesity and T2DM $[6,7]$.

Despite the availability of an array of antidiabetic medications, complications of diabetes continue to pose major challenges [8]. The pathogenesis of T2DM and its management by oral hypoglycemic agents have stimulated great interest in the recent past. Many plants have antidiabetic [9] and anti-obesity properties to varying degrees [10]. Indeed, plants may be utilized as alternatives to the common pharmacological treatments for diabetes and obesity [11]. Traditional medicines are widely used for diabetes treatment and management in Kenya [13]. However, few plants have been scientifically evaluated for their antidiabetic properties and efficacy [12]. Therefore, Mangifera indica L, Lonchocarpus eriocalyx (Harms), Urtica massaica Mildbr., Schkuhria pinnata (Lam) and Launaea cornuta, commonly used by the people of Embu and Mbeere counties of Kenya to treat diabetes [13], were investigated for their antidiabetic properties.

\section{EXPERIMENTAL}

\section{Plant materials and preparation of extracts}

Permission to collect plant samples was granted by Kenya Plant Health Inspectorate Services (KEPHIS), in accordance with the framework of the United Nations Convention on biodiversity materials. Plant parts from Mangifera indica L., Lonchocarpus eriocalyx (Harms), Urtica massaica Mildbr., Schkuhria pinnata (Lam) and Launaea cornuta (Table 1) were collected from Embu and Mbeere counties, Kenya. Identification was performed by an herbalist, and scientific authentication was performed by a taxonomist from the National Museums of Kenya. The collected plant specimens were given voucher numbers, and specimens were deposited with the National Museums of Kenya Herbarium. Materials were then air-dried and ground using a plant mill at Jomokenyatta University of Agriculture and Technology (JKUAT), Kenya. Samples were transported and stored sealed, excluding moisture, at room temperature.

In each case, $200 \mathrm{~g}$ of plant material was extracted with $6 \mathrm{~L} \mathrm{H}_{2} \mathrm{O}$ for $2 \mathrm{~h}$ at 92 to $95{ }^{\circ} \mathrm{C}$, filtered, and centrifuged at $6100 \times \mathrm{g}$ for $10 \mathrm{~min}$ at
$4{ }^{\circ} \mathrm{C}$, and the supernatant was collected and concentrated to $500 \mathrm{~mL}$ using a rotavaporizer (Rotavapor, Büchi RE 111, Switzerland). For determination of a-glucosidase and lipase activities, the residue of aqueous extraction was re-extracted with $6 \mathrm{~L}$ of absolute ethanol for $2 \mathrm{~h}$ at $37^{\circ} \mathrm{C}$, filtered, and centrifuged at $6100 \times \mathrm{g}$ for $10 \mathrm{~min}$ at $4{ }^{\circ} \mathrm{C}$, and the supernatant was collected and concentrated to $300 \mathrm{~mL}$.

\section{Determination of the $\alpha$-glucosidase inhibitory activity of plant extracts}

The $\alpha$-glucosidase inhibitory activity of ethanolic plant extracts was determined according to Li et al [14]. Briefly, $950 \mu \mathrm{L}$ of $100 \mathrm{mM}$ phosphate buffer ( $\mathrm{pH}$ 6.8) plus $40 \mu \mathrm{L}$ of $\alpha$-glucosidase solution (1 unit/mL; EC 3.2.1.20 from Saccharomyces cerevisiae; Sigma-Aldrich, Taufkirchen, Germany) and $10 \mu \mathrm{L}$ of plant extract (sample), ethanol (blank, corresponding to $100 \%$ enzyme activity) or the a-glucosidase inhibitor acarbose at a concentration at which, according to the literature, $50 \%$ inhibition is to be expected (IC50, positive control), were incubated at $37^{\circ} \mathrm{C}$ for $5 \mathrm{~min}$. Then, $30 \mu \mathrm{L}$ of $25 \mathrm{mM}$ p-nitrophenyl-Dglucopyranoside (pNPG; Sigma-Aldrich, Taufkirchen, Germany) was added, and the reaction mixture was incubated at $37^{\circ} \mathrm{C}$ for an additional $15 \mathrm{~min}$. The reaction was stopped by adding $1000 \mu \mathrm{l}$ of $0.5 \mathrm{~mol} / \mathrm{L}$ TRIS buffer (tris(hydroxymethyl) aminomethan; SigmaAldrich, Taufkirchen, Germany). Absorbance (A) was measured at $400 \mathrm{~nm}$, and inhibition rates were calculated as a percent of blank control as in Eq 1.

Inhibition $(\%)=100-\left(A_{\text {sample }} / A_{\text {blank }}\right) \times 100 \ldots(1)$

\section{Determination of lipase inhibitory activity}

Lipase activity was determined using the methylresofurin method as described by Möller et al [10]. In this colorimetric assay, red 6methylresorufin is released by lipase from the chromogenic lipase substrate 1,2-O-dilauryl-racglycero-3-glutaric acid-(6-methylresorufin)-ester. A mixture of $25 \mu \mathrm{L}$ crude type II porcine lipase (9 $\mathrm{U} / \mathrm{mL}$, Sigma-Aldrich, Taufkirchen, Germany), $200 \mu \mathrm{L}$ of $50 \mathrm{mM}$ BICINE buffer pH 8 (N,N-bis(2hydroxyethyl)glycine; Sigma-Aldrich, Taufkirchen, Germany) and $25 \mu \mathrm{L}$ of either alcoholic plant extract (1:100), ethanol (blank) or orlistat (tetrahydrolipstatin) at a concentration at which, according to the literature, $100 \%$ inhibition is to be expected (positive control), was incubated at $37{ }^{\circ} \mathrm{C}$ for $23 \mathrm{~min}$ to ensure an effective interaction between the lipase and (potentially) lipase-inhibiting substances. After the addition of 1,2-O-dilauryl-rac-glycero-3- 
glutaric acid-(6-methylresorufin)-ester, the mixture was incubated again at $37^{\circ} \mathrm{C}$ for an additional $3 \mathrm{~min}$, and the lipase activity was determined based on the increase in absorbance (A) at $580 \mathrm{~nm}$ due to the 6-methylresofurin released. Percent inhibition was calculated according to Eq 2.

Inhibition $(\%)=100-(\Delta$ Asample $/ \Delta$ Ablank $) \times 100$ ....... (2)

where $\Delta \mathrm{A}=$ increase in absorption at $580 \mathrm{~nm}$ during incubation).

\section{Animals and diets}

All aspects of animal care and experimentation were performed in agreement with the Guide for Care and Use of Laboratory Animals of the National Institutes of Health (NIH) [15] and were in accordance with the EEC directive of 1986 (86/609/EEC) [16]. The study was approved by the ethical committee of the Ministry for Agriculture, the Environment and Rural Areas of Schleswig-Holstein (approval no. V31172241.123-5(9-1/11).

Three-week-old male Wistar rats (Wistar Han IGS, Strain code: 273, Charles Rivers, Sulzfeld,
Germany) were housed individually in wired cages and maintained on Ssniffß NR pellets (Ssniff® Spezialdiäten, Soest, Germany; Table 2) and water ad libitum for 1 to 2 weeks (until they reached $150 \mathrm{~g}$ ) in ambient temperature and humidity with a $12 \mathrm{~h}$ light-dark cycle (lights on at 07:00).

Starting at approximately five weeks of age, the rats were given a high-fat and high-fructose diet (HFFD; Table 2), which was prepared by mixing $40 \mathrm{~g}$ of lard and $20 \mathrm{~g}$ of fructose with $100 \mathrm{~g}$ Ssniff@- NR powder in a laboratory blender (Table 2). At six weeks of age and $196 \pm 11 \mathrm{~g}$ body weight, rats were randomly allocated to 6 groups that were fed either HFFD only (control) or the HFFD plus one of the extracts from the following plants: Mangifera indica, Lonchocarpus eriocalyx, Urtica massaica, Schkuhria pinnata, or Launaea cornuta for 74 days (Table 2). The latter diets were prepared by spraying alcoholic $(\sim 300 \mathrm{~mL})$ and aqueous $(\sim 500 \mathrm{~mL})$ liquid plant extracts onto the HFFD powder in such amounts that the average daily feed intake of the rats provided $240 \mathrm{mg} / \mathrm{rat} /$ day of dry, not-yet-extracted plant material, in an amount equivalent to the daily dose recommended to people for medicinal purposes by the Kenyan herbalists.

Table 1: Name, voucher specimen number, plant parts used, and yield of ethanolic and aqueous extracts of five selected plants used for diabetes treatment in Kenya

\begin{tabular}{|c|c|c|c|c|c|}
\hline \multirow{2}{*}{$\begin{array}{l}\text { Scientific name, (Common } \\
\text { name). } \\
\text { Author }\end{array}$} & \multirow[t]{2}{*}{ Family name } & \multirow{2}{*}{$\begin{array}{l}\text { Voucher } \\
\text { specimen } \\
\text { number }\end{array}$} & \multirow{2}{*}{$\begin{array}{l}\text { Plant part } \\
\text { collected }\end{array}$} & \multicolumn{2}{|c|}{ Yield [\%] ${ }^{1}$} \\
\hline & & & & $\mathrm{EtOH}$ & $\mathrm{H}_{2} \mathrm{O}$ \\
\hline $\begin{array}{l}\text { Mangifera indica L. (Mango). } \\
\text { Linnaeus }\end{array}$ & Anacardiaceae & BKM2010/001 & Shoot & 0.005 & 0.010 \\
\hline $\begin{array}{l}\text { Lonchocarpus eriocalyx } \\
\text { (Harms). Gillet, Polhill } \\
\text { and Verdcourt }\end{array}$ & Leguminosae & BKM2010/002 & Bark & 0.003 & 0.004 \\
\hline $\begin{array}{l}\text { Urtica massaica Mildr. (Stinging } \\
\text { nettle). Linnaeus }\end{array}$ & Urticaceae & BKM2010/003 & Leaf \& Stalk & 0.003 & 0.005 \\
\hline $\begin{array}{l}\text { Schkuhria pinnata } \\
\text { (Curious weed). Thell }\end{array}$ & Asteraceae & BKM2010/004 & Whole plant & 0.003 & 0.010 \\
\hline $\begin{array}{l}\text { Launaea cornuta (Wild lettuce). } \\
\text { Jeffrey }\end{array}$ & Asteraceae & BKM2010/005 & Whole plant & 0.003 & 0.005 \\
\hline
\end{tabular}

Table 2: Nutritional composition of the experimental diets

\begin{tabular}{|c|c|c|c|c|c|c|c|}
\hline \multirow{2}{*}{$\begin{array}{l}\text { Diet } \\
\text { Nutrient }\end{array}$} & \multicolumn{2}{|c|}{ Ssniff ${ }^{\circledR}$ NR } & \multicolumn{2}{|c|}{ HFFD } & \multicolumn{3}{|c|}{ HFFD + extract } \\
\hline & $(\mathrm{g} / 100 \mathrm{~g})$ & $(\mathrm{kJ} / 100 \mathrm{~g})$ & $(g / 100 g)$ & $(k J / 100)$ & $(\mathrm{g} / 100 \mathrm{~g})$ & $(\mathrm{kJ} / 100 \mathrm{~g})$ & $(m g)$ \\
\hline Crude protein & 26.1 & 437 & 16.3 & 273 & 16.3 & 273 & \\
\hline Crude fat & 5.8 & 218 & 28.6 & 1078 & 28.6 & 1078 & \\
\hline Starch & 26.9 & 450 & 16.8 & 281 & 16.8 & 281 & \\
\hline Sugar ${ }^{1}$ & 8.8 & 147 & 18.0 & 301 & 18.0 & 301 & \\
\hline Plant extract & & & & & & & $240^{2}$ \\
\hline
\end{tabular}


Blood collection, body weight, feed intake and organ harvesting

Venous blood samples were collected into ethylenediaminetetraacetic acid (EDTA) tubes at the beginning (day 0 ) from the retrobulbar venous plexus and at the end (day 74) of the intervention from the abdominal aorta. Body weight was recorded weekly, and feed intake was recorded thrice weekly. At the end, after a $12 \mathrm{~h}$ fast, the rats were anesthetized using ketamine-xylazine anesthesia (mixed in a $4: 1$ ratio) administered at $0.25 \mathrm{~mL} / 100 \mathrm{~g}$ body weight intraperitoneally between 7.30 and $11.30 \mathrm{~h}$ and were then sacrificed using cardiac puncture injection. Plasma was immediately separated by centrifugation $(4000 \times \mathrm{g}$ for $10 \mathrm{~min})$. At the end of the intervention, samples from liver, visceral fat, subcutaneous fat and skeletal muscle ( $M$. femoris) were taken, weighed, snap frozen and then stored at $-20{ }^{\circ} \mathrm{C}$ until further analysis. Urine was collected over a four-day period at the beginning and end of the experimental period.

\section{Determination of biochemical parameters}

Insulin resistance was assessed using homeostasis model assessment (HOMA-IR = [fasting insulin $(\mu \mathrm{U} / \mathrm{mL}) \times$ fasting glucose $(\mathrm{mmol} / \mathrm{L})] / 405)$ [17]. Fasting plasma glucose (FPG), urinary glucose, glycated hemoglobin (HbA1c), plasma triglycerides (TG), total cholesterol (TC), low-density lipoprotein cholesterol (LDL-C), high-density lipoprotein cholesterol (HDL-C), aspartate aminotransferase (AST) and alanine aminotransferase (ALT) were determined enzymatically using commercially available kits (Thermo Fisher Scientific, Passau, Germany) on a Konelab 20i clinical chemistry analyzer (Kone, Helsinki, Finland). The atherogenic index (LDL-C/HDL-C) and coronary risk index (TG/HDL-C and TC/HDL-C) were calculated according to [18]. Triglycerides from liver, visceral fat, subcutaneous fat and skeletal muscle were extracted using the Folch method. The contents of the extracts were measured enzymatically using a commercially available kit (Thermo Fisher Scientific, Passau, Germany).

\section{Statistical analysis}

In accordance with the main purpose of the present study, i.e., to test the potential antidiabetic properties of plant extracts, glycated hemoglobin $(\mathrm{HbA} 1 \mathrm{c})$ was defined as the primary parameter of the study because it reflects the mean glucose concentration over a longer period. In previous studies, feeding Wistar rats a fat- and fructose-rich diet resulted in $\% \mathrm{HbA} 1 \mathrm{c}$ values of $4.2 \pm 0.3$ (mean $\pm S D$ ). The increase in
$\% \mathrm{HbA} 1 \mathrm{c}$ after 10 weeks of HFFD diet feeding was $0.53 \pm 0.41$. Assuming that a $10 \%$ decrease in plasma $\% \mathrm{HbA} 1 \mathrm{c}$ (or a partial reversal of approximately $66 \%$ of the HFFD-induced plasma $\% \mathrm{HbA} 1 \mathrm{c}$ increase) by the extracts is physiologically relevant, a minimum number of 10 rats per group was calculated, whereby the calculation was based on an $\alpha$-value of 0.01 (to account for multiple testing) and a $\beta$-value of 0.10 . This number was increased to 15 rats per group to account for drop-outs during the 15week trial period and for the fact that unusable retrobulbar blood samplings could not be repeated for animal welfare reasons.

Mean values of the control and five plant groups were compared separately for each parameter. Statistical significance was accepted at $p<0.05$ and was tested using Welch's analysis of variance (Welch's ANOVA) due to heterogeneity of variances, with Dunnett's T3 post hoc test to test for significant differences between plant groups and the control. Statistical analysis was performed using the Statistical Package for the Social Science (SPSS for Windows, version 18.0, Chicago, IL).

To examine to what extent individual parameters or the combination of parameters might contribute to the postulated health effects in the study, a discriminant analysis was carried out using the software package "Statgraphics Plus for Windows" (version 4.5, Manugistics, Rockville, MD, USA).

\section{RESULTS}

Effect of plant extracts on pancreatic lipase
and $\alpha$-glucosidase activity in vivo

At 1:100 ethanol extract dilutions, all extracts inhibited pancreatic lipase (PL) by at least $29 \%$ in vitro but did not inhibit a-glucosidase activity (Table 3).

\section{Effect of plant extracts on the weight and energy intake of rats}

Weight gain and decrease in energy intake were similar in all groups ( $p>0.05$; Welch ANOVA) (Table 4 a).

\section{Effect of plant extracts on glucose metabolism and insulin resistance of rats}

Compared to the control, plant extracts caused slight, nonsignificant $(p>0.7$ or $p>0.2$, respectively) changes in the concentrations of fasting blood glucose (FBG) and urinary glucose ranging between -10 and $-25 \%$ (SP extracts =

Trop J Pharm Res, October 2020; 19(10): 2140 
$+0.5 \%$ ) or between -16 and $-148 \%$, respectively (Table 4 b). The HbA1c increase was also nonsignificantly lower than that of the control, whereby the reductions ranged from -1 to $-22 \%$. For all three parameters, the UM extracts showed the strongest effect (Table $4 \mathrm{~b}$ ).

\section{Effects of plant extracts on ALT and AST activity in rats}

Except for the LC and MI groups, in which ALT activity was non-significantly increased, plasma ALT and AST were reduced non-significantly by the extracts in comparison to the control, with the highest reduction observed for UM extracts (Table 4 b).

\section{Effects of plant extracts on plasma lipids and atherogenic indices of rats}

The majority of the tested plant extracts decreased plasma lipid concentrations and atherogenic indices non-significantly by -40 to $79 \%$ (TG), up to $-42 \%$ (LDL-C), up to $-0.74 \%$ (HDL-C), up to $-92 \%$ (cholesterol), up to $-83 \%$ (LDL/HDL), up to $-55 \%$ (TG/HDL) and up to -106 $\%$ (TC/HDL) at the end of the experiment compared to the control group. UM showed the most favorable changes.

Neither Welch ANOVA (global p) nor multiple comparisons by Dunnett's test showed significant effects with the exception of $\Delta$ plasma TG for UM versus the control group (Table $4 \mathrm{~b}$ ).

\section{Effects of plant extracts on liver weight and lipid concentrations in selected tissues}

In all groups except MI, liver weight at the end of the experiment was slightly and non-significantly increased by 1 to $3 \%$ relative to the control (Table 4a).
The fat and TG mean values were increased by 3 to $10 \%$ fat and 3 to $15 \%$ TG only in the LE and SP groups, while the LC, MI, and UM extracts reduced the fat and TG mean values in the liver by 2 to $11 \%$ fat or 15 to $40 \%$ TG. Only the global effect of plant extracts on liver TG was significant ( $p=0.03$, Welch ANOVA); the multiple post hoc comparisons of the verum groups with the control (Fisher's Least Significant Difference (LSD)) revealed that this significance was primarily due to the liver TG reduction by the LC and UM extracts. According to the more conservative Dunnett test, this difference was not significant (Table 4a).

Moreover, plant extracts did not significantly reduce the fat and TG concentrations in muscle tissues by 44 to $67 \%$ (fat) and 12 to $61 \%$ (TG), respectively, compared to the control group. In subcutaneous or visceral tissue, they increased fat (except MI and UM) concentrations by 2 to 3 $\%$ or 5 to $11 \%$ and TG concentrations by 11 to $23 \%$ or 4 to $17 \%$, respectively (Table 4 a).

\section{Results of discriminant analysis}

Statistical analysis with (discriminant analytically determined) combinations of such parameters that are associated with the respective health effect did not reveal any additional significance of the effects (data not shown).

\section{DISCUSSION}

The results from in vitro assays showed that the plant extracts had only pancreatic lipase inhibitory effects but no a-glucosidase inhibitory effects. This indicates that most plants used for T2DM treatment in Kenyan traditional medicine possess anti-lipase activity and not anti-glycemic effects.

Table 3: Inhibition of lipase and a-glucosidase in vitro by ethanolic extracts from selected Kenyan plants

\begin{tabular}{lcc}
\hline \multirow{2}{*}{ Plant } & \multicolumn{2}{c}{ Enzyme inhibition (\%) } \\
\cline { 2 - 3 } Mangifera indica L. (Mango) & Pancreatic lipase & a-Glucosidase \\
a & 3.0 \\
Lonchocarpus eriocalyx (Harms) & 46.3 & -16.0 \\
Urtica massaica (stinging nettle) & 29.0 & -17.0 \\
Schkuhria pinnata & 45.5 & -15.0 \\
Launaea cornuta & 49.6 & -19.0 \\
Orlistat & 99.8 & - \\
Acarbose, $\mathrm{IC}_{50}$ & - & 52.1 \\
\hline
\end{tabular}

${ }^{a}$ Results represent double measurements of in vitro pancreatic lipase and a-glucosidase enzyme activities in the presence of 1:100 dilutions of Mangifera indica (MI), Lonchocarpus eriocalyx (LE), Launaea cornuta (LC), Urtica massaica (UM) and Schkuhria pinnata (SP) ethanolic extracts compared to the blank $(0 \mathrm{mg} / \mathrm{mL}$ of plant extract = $100 \%$ activity). This (residual) enzyme activity was transformed into \% inhibition by subtracting it from 100 . Orlistat or acarbose, respectively, were used as positive controls for lipase or a-glucosidase inhibition and were added in concentrations at which, according to the literature, $100 \%$ or $50 \%$ inhibition is to be expected 
Table 4a: Effect of ethanol extracts of Launaea cornuta (LC), Lonchocarpus eriocalyx (LE), Mangifera indica (MI), Schkuhria pinnata (SP) and Urtica massaica (UM) on rats fed a high fat and fructose diet - metabolic and organ parameters ${ }^{1}$

\begin{tabular}{|c|c|c|c|c|c|c|c|c|c|c|c|c|c|}
\hline \multirow{3}{*}{$\begin{array}{l}\text { Metabolic parameters } \\
\Delta \text { Body weight }(\mathrm{g})\end{array}$} & CON & $\mathrm{n}$ & LC & $\mathrm{n}$ & LE & $\mathrm{n}$ & MI & $\mathrm{n}$ & SP & $\mathrm{n}$ & UM & $\mathrm{n}$ & $P$-value \\
\hline & & & & & & & \multirow{3}{*}{$\begin{array}{r}232 \pm 18.7^{a} \\
-26.5 \pm \\
37.4^{a}\end{array}$} & & & & \multirow{3}{*}{$\begin{array}{r}212 \pm 24.9^{a} \\
-26.8 \pm \\
24.8^{a}\end{array}$} & \multirow[b]{2}{*}{14} & \multirow{3}{*}{0.22} \\
\hline & $\begin{array}{r}230 \pm 40.2^{\mathrm{a}} \\
-24.9 \pm\end{array}$ & 14 & $\begin{array}{r}220 \pm 30.1^{\mathrm{a}} \\
-12.2 \pm\end{array}$ & 14 & $\begin{array}{r}221 \pm 24.6^{a} \\
-9.47 \pm\end{array}$ & 14 & & 14 & $\begin{array}{r}218 \pm 35.6^{a} \\
-16.2 \pm\end{array}$ & 15 & & & \\
\hline$\Delta$ Energy intake ( $\mathrm{kJ} /$ day) & $26.1^{a}$ & 14 & $33.9^{a}$ & 14 & $33.6^{a}$ & 14 & & 14 & $37.5^{\mathrm{a}}$ & 15 & & 14 & \\
\hline \multicolumn{14}{|l|}{ Organ parameters } \\
\hline Liver weight (g) & $\begin{array}{r}9.23 \pm 2.45^{\mathrm{a}} \\
5.07 \pm\end{array}$ & 13 & $9.42 \pm 1.06^{a}$ & 14 & $\begin{array}{r}9.40 \pm 1.28^{\mathrm{a}} \\
5.24 \pm\end{array}$ & 14 & $\begin{array}{r}9.23 \pm 2.22^{\mathrm{a}} \\
4.99 \pm\end{array}$ & 14 & $9.48 \pm 1.16^{a}$ & 15 & \multirow{5}{*}{$\begin{array}{r}9.30 \pm 1.32^{\mathrm{a}} \\
4.72 \pm \\
1.15^{\mathrm{ab}} \\
8.06 \pm \\
4.35^{\mathrm{ab}} \\
1.82 \pm \\
1.61^{\mathrm{ab}} \\
10.3 \pm \\
11.0^{\mathrm{ab}}\end{array}$} & & 0.99 \\
\hline Liver fat (\%) & $\begin{array}{l}0.76^{\mathrm{ab}} \\
11.7 \pm\end{array}$ & 13 & $4.52 \pm 1.62^{a}$ & 14 & $1.54^{\mathrm{ab}}$ & 12 & $\begin{array}{l}1.16^{\mathrm{ab}} \\
9.94 \pm\end{array}$ & 13 & $\begin{array}{r}5.59 \pm 1.63^{b} \\
12.1 \pm\end{array}$ & 14 & & 13 & 0.56 \\
\hline Liver TG (mg/g) & $7.30^{\mathrm{ab}}$ & 13 & $\begin{array}{r}7.09 \pm 3.85^{\mathrm{a}} \\
2.05 \pm\end{array}$ & 14 & $13.4 \pm 6.15^{b}$ & 12 & $5.39^{a b}$ & 13 & $10.9^{a b}$ & 14 & & 13 & $0.04^{*}$ \\
\hline Muscle fat (\%) & $3.66 \pm 4.70^{\mathrm{b}}$ & 9 & $\begin{array}{l}1.69^{\mathrm{ab}} \\
14.8 \pm\end{array}$ & 10 & $1.19 \pm 0.77^{a}$ & 11 & $\begin{array}{r}1.25 \pm 0.8^{\mathrm{a}} \\
7.24 \pm\end{array}$ & 11 & $\begin{array}{r}1.53 \pm 0.66^{a} \\
10.2 \pm\end{array}$ & 12 & & 11 & 0.50 \\
\hline Muscle TG (mg/g) & $\begin{array}{r}16.9 \pm 16.8^{\mathrm{a}} \\
84.9 \pm\end{array}$ & 9 & $17.0^{\mathrm{ab}}$ & 10 & $6.54 \pm 4.55^{b}$ & 11 & $\begin{array}{l}6.20^{\mathrm{ab}} \\
81.1 \pm\end{array}$ & 11 & $3.94^{\mathrm{ab}}$ & 11 & & 11 & 0.27 \\
\hline $\begin{array}{l}\text { Subcutaneous tissue fat (\%) } \\
\text { Subcutaneous tissue TG }\end{array}$ & $4.69^{a b}$ & 9 & $87.8 \pm 4.57^{\mathrm{b}}$ & 13 & $86.2 \pm 5.32^{b}$ & 12 & $22.2^{\mathrm{ab}}$ & 13 & $86.7 \pm 5.87^{b}$ & 15 & $73.9 \pm 22.9^{a}$ & 13 & 0.19 \\
\hline$(\mathrm{mg} / \mathrm{g})$ & $510 \pm 165^{a}$ & 13 & $626 \pm 186^{a}$ & 13 & $565 \pm 191^{a}$ & 12 & $588 \pm 175^{a}$ & 13 & $617 \pm 163^{a}$ & 15 & $621 \pm 1234^{a}$ & 13 & 0.52 \\
\hline Visceral tissue fat (\%) & $88.0 \pm 13.8^{a}$ & 9 & $97.3 \pm 3.74^{a}$ & 13 & $94.4 \pm 1.75^{\mathrm{a}}$ & 11 & $92.3 \pm 3.77^{a}$ & 11 & $93.3 \pm 3.66^{a}$ & 14 & $87.7 \pm 25.5^{a}$ & 11 & 0.35 \\
\hline Visceral tissue TG (mg/g) & $655 \pm 118^{a}$ & 9 & $728 \pm 120^{\mathrm{a}}$ & 13 & $766 \pm 146^{a}$ & 11 & $754 \pm 164^{a}$ & 11 & $719 \pm 110^{\mathrm{a}}$ & 14 & $679 \pm 195^{a}$ & 11 & 0.56 \\
\hline
\end{tabular}

${ }^{1}$ Male Wistar rats were given either a high fat and fructose diet (HFFD) without (CON= control) or combined with one of the following plant extracts (equivalent to 240 mg dry plant material/rat/day): LC= Launaea cornuta, LE= Lonchocarpus eriocalyx, MI= Mangifera indica, SP= Schkuhria pinnata and UM= Urtica massaica for 74 days. Values represent changes between the start and end of experiment (end minus start value) or, in the case of organ parameters, the end values only and are expressed as the mean \pm standard deviation (SD). The percentage fat content is calculated from the wet weight of the organs. ${ }^{*} p<0.05$ is significant (Welch ANOVA), superscripts with the same letters in the same row are not different from each other (LSD multiple comparison test) 
Table 4b: Effect of ethanol extracts of Launaea cornuta (LC), Lonchocarpus eriocalyx (LE), Mangifera indica (MI), Schkuhria pinnata (SP) and Urtica massaica (UM) on blood parameters of rats fed a high fat and fructose diet ${ }^{1}$

\begin{tabular}{|c|c|c|c|c|c|c|c|c|c|c|c|c|c|}
\hline & CON & $\mathbf{n}$ & LC & $\mathbf{n}$ & LE & $\mathbf{n}$ & MI & $\mathbf{n}$ & SP & $\mathbf{n}$ & UM & $\mathbf{n}$ & $\begin{array}{l}P \text { - } \\
\text { value }\end{array}$ \\
\hline Insulin and glycemia & & & & & & & & & & & & & \\
\hline $\begin{array}{l}\Delta \text { Plasma glucose } \\
\text { [mg/dL] } \\
\Delta \text { Urinary glucose }\end{array}$ & $189 \pm 139^{a}$ & 13 & $171 \pm 89.2^{\mathrm{a}}$ & 12 & $153 \pm 108^{a}$ & 13 & $154 \pm 74.2^{\mathrm{a}}$ & 11 & $190 \pm 123^{a}$ & 14 & $142 \pm 113^{a}$ & 14 & 0.79 \\
\hline$[\mathrm{mg} / \mathrm{dl}]$ & $1.98 \pm 3.84^{b}$ & 14 & $0.28 \pm 3.56^{a b}$ & 14 & $1.67 \pm 5.14^{\mathrm{ab}}$ & 14 & $0.75 \pm 3.64^{\mathrm{ab}}$ & 14 & $0.12 \pm 2.62^{\mathrm{ab}}$ & 15 & $-0.96 \pm 2.44^{a}$ & 14 & 0.28 \\
\hline$\Delta \% \mathrm{HbA} 1 \mathrm{c}$ & $\begin{array}{r}0.73 \pm 0.27^{a} \\
-0.80 \pm\end{array}$ & 14 & $0.58 \pm 0.41^{a}$ & 14 & $0.62 \pm 0.23^{a}$ & 13 & $0.72 \pm 0.30^{a}$ & 14 & $0.68 \pm 0.35^{a}$ & 14 & $0.57 \pm 0.23^{a}$ & 14 & 0.34 \\
\hline$\Delta$ Insulin [ng/ml] & $\begin{array}{r}1.13^{a} \\
-4.06 \pm\end{array}$ & 14 & $-0.52 \pm 0.80^{a}$ & 13 & $-0.51 \pm 0.96^{a}$ & 13 & $-0.42 \pm 1.04^{a}$ & 14 & $-0.39 \pm 0.95^{a}$ & 14 & $-0.40 \pm 0.78^{a}$ & 14 & 0.86 \\
\hline $\begin{array}{l}\Delta \text { HOMA-IR } \\
\text { Plasma lipids }\end{array}$ & $16.0^{\mathrm{a}}$ & 11 & $-0.44 \pm 8.97^{a}$ & 12 & $-0.05 \pm 14.4^{a}$ & 13 & $0.53 \pm 17.5^{a}$ & 10 & $4.73 \pm 14.6^{a}$ & 14 & $-1.01 \pm 11.3^{a}$ & 14 & 0.67 \\
\hline$\Delta$ Plasma TG $(\mathrm{mg} / \mathrm{dl})$ & $\begin{array}{r}70.9 \pm 82.7^{b} \\
-5.18 \pm\end{array}$ & 13 & $42.3 \pm 47.6^{a b}$ & 12 & $25.5 \pm 66.9^{a b}$ & 13 & $21.0 \pm 43.6^{a b}$ & 10 & $26.5 \pm 42.9^{a b}$ & 14 & $15.2 \pm 40.1^{\mathrm{a}}$ & 13 & 0.44 \\
\hline$\Delta \mathrm{LDL}(\mathrm{mg} / \mathrm{dl})$ & $\begin{array}{r}6.68^{\mathrm{a}} \\
-6.05 \pm\end{array}$ & 13 & $-6.76 \pm 3.90^{a}$ & 12 & $-6.93 \pm 3.53^{a}$ & 13 & $-4.16 \pm 5.09^{a}$ & 10 & $-7.38 \pm 4.11^{a}$ & 14 & $-5.88 \pm 3.91^{a}$ & 13 & 0.76 \\
\hline$\Delta \mathrm{HDL}(\mathrm{mg} / \mathrm{dl})$ & $\begin{array}{r}23.1^{\mathrm{a}} \\
-8.78 \pm\end{array}$ & 13 & $-9.40 \pm 10.3^{a}$ & 12 & $-5.80 \pm 11.4^{\mathrm{a}}$ & 12 & $-7.75 \pm 7.77^{a}$ & 11 & $-10.5 \pm 8.78^{a}$ & 14 & $-7.39 \pm 8.11^{a}$ & 13 & 0.82 \\
\hline$\Delta \mathrm{TC}(\mathrm{mg} / \mathrm{dl})$ & $\begin{array}{r}18.8^{a} \\
-0.06 \pm\end{array}$ & 12 & $-8.01 \pm 12.4^{a}$ & 13 & $-8.99 \pm 17.2^{\mathrm{a}}$ & 13 & $-14.5 \pm 17.5^{a}$ & 11 & $-16.9 \pm 16.0^{a}$ & 14 & $-10.7 \pm 14.7^{a}$ & 13 & 0.69 \\
\hline$\Delta \mathrm{LDL} / \mathrm{HDL}$ & $0.05^{\mathrm{a}}$ & 10 & $-0.08 \pm 0.10^{a}$ & 12 & $-0.11 \pm 0.09^{a}$ & 12 & $-0.07 \pm 0.05^{a}$ & 9 & $-0.10 \pm 0.08^{a}$ & 14 & $-0.09 \pm 0.07^{a}$ & 13 & 0.56 \\
\hline$\Delta \mathrm{TC} / \mathrm{HDL}$ & $0.16 \pm 0.24^{a}$ & 10 & $0.14 \pm 0.30^{a}$ & 12 & $0.16 \pm 0.49^{a}$ & 12 & $-0.01 \pm 0.26^{a}$ & 9 & $0.27 \pm 0.34^{a}$ & 13 & $-0.00 \pm 0.31^{a}$ & 12 & 0.61 \\
\hline $\begin{array}{l}\Delta \mathrm{TG} / \mathrm{HDL} \\
\text { Steatosis parameters }\end{array}$ & $1.30 \pm 1.37^{a}$ & 10 & $1.39 \pm 1.27^{a}$ & 11 & $1.09 \pm 1.75^{a}$ & 12 & $1.30 \pm 1.93^{a}$ & 9 & $0.89 \pm 1.12^{a}$ & 14 & $0.59 \pm 0.90^{\mathrm{a}}$ & 13 & 0.54 \\
\hline$\Delta \mathrm{AST}(\mathrm{U} / \mathrm{L})$ & $\begin{array}{r}-19.1 \pm \\
55.1^{a} \\
-3.30 \pm\end{array}$ & 13 & $-24.6 \pm 9.78^{a}$ & 11 & $-32.1 \pm 16.2^{a}$ & 13 & $-26.0 \pm 39.3^{a}$ & 10 & $-27.6 \pm 20.0^{a}$ & 13 & $-36.6 \pm 42.3^{a}$ & 13 & 0.72 \\
\hline$\Delta \mathrm{ALT}(\mathrm{U} / \mathrm{L})$ & $7.67^{a}$ & 13 & $3.22 \pm 17.9^{a}$ & 12 & $-4.78 \pm 7.28^{a}$ & 13 & $-2.61 \pm 6.47^{a}$ & 10 & $-5.84 \pm 14.6^{a}$ & 14 & $-6.6 \pm 41.9^{a}$ & 13 & 0.68 \\
\hline
\end{tabular}

${ }^{1}$ Male Wistar rats were given either a high fat and fructose diet (HFFD) without (CON=control) or combined with one of the following plant extracts (equivalent to 240 mg dry plant material/rat/day): LC= Launaea cornuta, LE= Lonchocarpus eriocalyx, MI= Mangifera indica, SP= Schkuhria pinnata and UM= Urtica massaica for 74 days. $\Delta$ values represent changes between the start and end of experiment (start minus end values) and are expressed as the mean \pm standard deviation (SD). ${ }^{*} \mathrm{p}<0.05$ is significant (Welch ANOVA), superscripts with the same letters in the same row are not different from each other (LSD multiple comparison test). ALT (alanine transaminase); AST (aspartate transaminase); TG (plasma triglycerides); LDL (low-density lipoprotein cholesterol); HDL (high-density lipoprotein cholesterol); TC (total plasma cholesterol); \%HbA1c (glycosylated hemoglobin); HOMA-IR (homeostasis model assessment index for insulin resistance) 
This may be due to the abundance of lipase inhibitors in nature, as reported by some studies $99,10,19]$. In fact, in T2DM, both lipid and carbohydrate metabolism is affected [20], and delayed absorption of either lipids or carbohydrates is expected to exert beneficial effects on glucose and lipid metabolism. However, lipase inhibition in vitro does not necessarily predict in vivo effectiveness, since in vitro and in vivo effects may differ $[10,19]$.

The feeding experiments in rats showed significant effects of the plant extracts on liver triglycerides. In accordance with this, a more pronounced reduction in the markers of liver steatosis, AST and ALT, by UM; lower muscle fat under LE, MI and SP; and somewhat lower muscle triglycerides under LE, MI, SP and UM were observed compared to those in the control condition. Furthermore, urinary glucose was reduced by UM, whereas it was increased in the control group, and the increase in plasma triglycerides was less pronounced in the UM group.

However, except for the increase or decrease in liver TG, where significance (global $p=0.04$ ) was due to effects between treatment groups, none of these effects was significant in Welch ANOVA or in multiple comparisons with the control group (Dunnett's test).

A major reason for the lack of statistical significance of the effects of the plant extracts could be that Kenyan plants with claimed antidiabetogenic effects are not a "factor" in the sense of ANOVA where the different plant extracts are categorized as "factor levels". Indeed, LC, LE, MI, SP and UM may be independent variables that should have been individually investigated in independent experiments and with their own control groups.

Additional reasons for the lack of statistical significance are the large standard deviation in the majority of parameters (up to a multiple of the mean) and the heterogeneity of the variances between the groups (heteroscedasticity). Violation of the prerequisites for an ANOVA is, in this regard probably of little importance because a Welch ANOVA was calculated, and further measures such as data transformation or the implementation of a nonparametric (KruskalWallis) test (data not shown) did not significantly influence the statistical statement.

More importantly, the group sizes in this study were too small (15 rats per group, of which 9 to 15 animals per group provided evaluable data at the end of the experiment). The number $n=15$ was chosen based on the results of a previous study [21], in which only a Lapacho tea extract was investigated using the same rat model. In fact, based on \%HbA1c or on HOMA-IR as the primary parameter, one would have needed up to 52 or 64 animals per group, respectively, to detect a significant effect of the plant extract with the largest mean difference from the control group. Based on this limitation, this study can provide only preliminary results.

Thus, the present study should be repeated for the most promising plant extracts in separate studies, with individual control groups and larger group sizes.

The liver may be affected in diabetes as a result of impaired glucose and lipid homeostasis [17]. Triglycerides may be deposited, causing liver steatosis [6]. The extracts, particularly LC and UM, had significant effects on liver triglycerides, which reduced liver triglycerides. However, liver weight and the proportion of total fat in the liver were low (<4.5\%) and/or inconsistently affected. Muscle triglycerides, total plasma triglycerides and cholesterol were reduced as well, but not significantly. Furthermore, hepatic triglyceride concentrations are usually correlated with ectopic fat accumulation [22]. The reduction in liver steatosis is in line with the in vitro results showing the lipase inhibitory effect of the extracts.

A diet that is high in fat and fructose causes overproduction of triglycerides, which are deposited in tissues, especially the liver, muscle, mesenterium and subcutaneous fat, causing insulin resistance and low-grade inflammation $[6,7]$. Liver biopsy is the ideal test for liver damage; however, ALT and AST are normally used as less costly and noninvasive biomarkers of liver damage [26]. The decreases in AST and $A L T$ in the plant extract groups were than in the herbal groups before intervention, this finding has to be taken with caution.

The results for Mangifera indica and Schkuhria pinnata extracts, in particular, were contradictory to reports showing their antidiabetic potential [24]. This could be a result of using a different rat model since in most of the studies, diabetes was chemically induced, while in the present study, diabetes was induced with a HFFD. Chemically induced diabetes may be reversed by factors such as antioxidants, which counteract the mechanism of toxins that damage Langerhans islets, whereas the HFFD induces T2DM predominantly by inducing insulin resistance. 
Diabetes mellitus type 2 increases cardiovascular risks [2] not only by glycation of proteins due to hyperglycemia but also by its association with low HDL-C, hypertriglyceridemia and small dense LDL-C [27]. There was no significant reduction in triglycerides, TG/HDL-C, TC, TC/HDL-C and LDL-C/HDL-C by the extracts, suggesting no reduced risk of cardiovascular disease $[2,4]$. Therefore, despite the tendency for improved glycemia by the extracts, lipoprotein abnormalities seem not to have been corrected. In prediabetes and insulin resistance, dyslipidemia may exist in the absence of hyperglycemia Hence, lipid abnormalities are in essence associated with abnormalities in insulin action and not hyperglycemia per se [19]. Therefore, in thiazolidinedione treatment, insulin action in peripheral tissues is enhanced, leading to greater improvements in lipid profiles than by other glucose-reducing agents [23]. According to the results of orlistat, the in vitro lipase inhibitory action of extracts would have been expected to reduce $T G$ s and $L D L-C$ independent of the effect on glucose levels [25].

Accordingly, although PL was inhibited in vitro by the extracts, they did not affect weight gain in comparison to the control. Indeed, components active in vitro may be inactive in the body [18] because in vivo conditions are much more complex than the model applied for in vitro testing and because the water-soluble substrate resorufin was used instead of emulsified micellar triglycerides. Furthermore, the active compound may be inactivated in vivo by gastric acid, digestive enzymes or binding to substances present in the ingesta but not in in vitro medium. The lack of effect on weight gain is in line with an absent or insufficient in vivo lipase inhibitory effect of the extracts.

\section{CONCLUSION}

The extracts show PL inhibition in vitro, and significantly reduced liver triglycerides in rats fed a HFFD. Glycemia tended to be improved, particularly in the case of Launuta cornea. However, the extracts did not improve hyperinsulinemia and insulin resistance (HOMAIR). Notably, inconsistencies in the antidiabetic effects of the extracts were observed, except for Urtica massaica extract, which showed consistent alterations of several traits of metabolic syndrome. Hence, further investigation of this extract is suggested to examine whether the observed effects may be confirmed with a larger sample size and whether they are dosedependent.

\section{DECLARATIONS}

\section{Acknowledgement}

We are grateful to Frauke Repenning and Kirsten Gonda for technical assistance and Jochen Kunze, Karina Horn and Dieter Siewertsen for animal care, G.M. Mungai for scientific authentication of the plants, Mwaniki for plant identification, J. K Mutembei and K. Bugesi for assistance with milling and drying of samples, $P$. Karanja for administrative assistance in the Food Science Department, and JKUAT and KEPHIS for permission to collect plant samples. Ms. Kiage received a scholarship from Jomo Kenyatta University, Nairobi, Kenya.

\section{Conflict of interest}

No conflict of interest is associated with this work.

\section{Contribution of authors}

We declare that this work was done by the authors named in this article and all liabilities pertaining to claims relating to the content of this article will be borne by the authors.

\section{Open Access}

This is an Open Access article that uses a funding model which does not charge readers or their institutions for access and distributed under the terms of the Creative Commons Attribution License (http://creativecommons.org/licenses/by/ 4.0) and the Budapest Open Access Initiative (http://www.budapestopenaccessinitiative.org/rea d), which permit unrestricted use, distribution, and reproduction in any medium, provided the original work is properly credited.

\section{REFERENCES}

1. Farag Y.M., \& Gaballa M.R. Diabesity: an overview of a rising epidemic. Nephrology Dialysis Transplantation. 2011; 26: 28-35.

2. Boden G., \& Shulman G. Free fatty acids in obesity and type 2 diabetes: defining their role in the development of insulin resistance and $\beta$-cell dysfunction. European journal of clinical investigation. 2002; 32: 14-23.

3. Sacks F.M., Tonkin A.M., Craven T., Pfeffer M.A., Shepherd J., Keech A., Furberg C.D., \& Braunwald E. Coronary heart disease in patients with low LDLcholesterol benefit of pravastatin in diabetics and enhanced role for HDL-cholesterol and triglycerides as risk factors. Circulation. 2002;105: 1424-1428.

Trop J Pharm Res, October 2020; 19(10): 2145 
4. Stern MP (1995). Diabetes and cardiovascular disease: the "common soil" hypothesis. Diabetes. 1999; 44: 369374.

5. Olsen N \& Heitmann B. Intake of calorically sweetened beverages and obesity. Obesity Reviews. 2009; 10: 6875 .

6. Farrell GC \& Larter CZ. Nonalcoholic fatty liver disease: from steatosis to cirrhosis. Hepatology. 2006; 43: S99S112.

7. Reuter TY. Diet-induced models for obesity and type 2 diabetes. Drug Discovery Today: Disease Models. 2007: 4: 3-8.

8. Amini $M$ \& Parvaresh E. Prevalence of macro-and microvascular complications among patients with type 2 diabetes in Iran: a systematic review. Diabetes Research and Clinical Practice. 2009: 83: 18-25.

9. Patel P, Harde P, Pillai J, Darji N \& Patel B. Antidiabetic herbal drugs a review. Pharmacophore. 2012; 3: 18-29.

10. Möller NP, Roos N \& Schrezenmeir J. Lipase inhibitory activity in alcohol extracts of worldwide occurring plants and propolis. Phytotherapy Research. 2009; 23: 585586.

11. Tucci SA, Boyland EJ \& Halford JC. The role of lipid and carbohydrate digestive enzyme inhibitors in the management of obesity: a review of current and emerging therapeutic agents. Diabetes, Metabolic Syndrome and Obesity: Targets and Therapy. 2010; 3: 125.

12. Jeruto $P$, Lukhoba $C$, Ouma $G$, Otieno $D$ \& Mutai $C$. Herbal treatments in Aldai and Kaptumo divisions in Nandi district, Rift valley province, Kenya. African Journal of Traditional, Complementary, and Alternative Medicines. 2008; 5: 103.

13. Kareru P, Kenji G, Gachanja A, Keriko J \& Mungai G. Traditional medicines among the Embu and Mbeere people of Kenya. African Journal of Traditional, Complementary and Alternative Medicines. 2007; 4: 7586.

14. Li Y, Peng G, Li Q, Wen S, Hsun-Wei Huang $T$, Roufogalis $B D$ \& Yamahara J. Salacia oblonga improves cardiac fibrosis and inhibits postprandial hyperglycemia in obese zucker rats. Life sciences. 2004; 75: 17351746.

15. National Institute of Health. Guide for Care and Use of Laboratory Animals. 1985, Publication No. 86-23, Bethesda, Maryland, USA

16. EC. Council Directive 86/609/EEC of 24 November 1986 on the approximation of laws, regulations and administrative provisions of the Member States regarding the protection of animals used for experimental and other scientific purposes (86/609/EEC) Official Journal L 358, Volume 29; 1986: 1 - 28; ISSN 0378-6978

17. Matthews $D$, Hosker J, Rudenski A, Naylor B, Treacher $D$ \& Turner R. Homeostasis model assessment: insulin resistance and $\beta$-cell function from fasting plasma glucose and insulin concentrations in man. Diabetologia. 1985; 28: 412-419.

18. Adeneye A \& Olagunju J. Preliminary hypoglycemic and hypolipidemic. Biology and Medicine. 2009; 1: 1-10.

19. Kiage-Mokua BN, Roos N \& Schrezenmeir J (2012). Lapacho tea (Tabebuia impetiginosa) extract inhibits pancreatic lipase and delays postprandial triglyceride increase in rats. Phytotherapy Research. 1957; 26: 1878-1883.

20. Van den Berghe $G$. The role of the liver in metabolic homeostasis: implications for inborn errors of metabolism. Journal of Inherited Metabolic Disease. 1991; 14: 407-420.

21. Kiage-Mokua $B N$, de Vrese $M$, Kraus-Stojanowic I, Nielsen A, Roos N, Ghadimi D \& Schrezenmeir J. Tabebuia impetiginosa extract (Lapacho tea) reduces hypertriglyceridemia and cardiovascular risk factors in Wistar rats fed high fructose and fat diet. International Journal of Pharmaceutical and Phytopharmacological Research. 2018; 8:39-45.

22. Poynard T, Ratziu V, Naveau S, Thabut D, Charlotte $F$, Messous D, Capron D, Abella A, Massard J \& Ngo Y. The diagnostic value of biomarkers (SteatoTest) for the prediction of liver steatosis. Comparative hepatology. 2005; 4: 10.

23. Burgert TS, Taksali SE, Dziura J, Goodman TR, Yeckel CW, Papademetris $X$, Constable RT, Weiss $R$, Tamborlane WV \& Savoye M. Alanine aminotransferase levels and fatty liver in childhood obesity: associations with insulin resistance, adiponectin, and visceral fat. The Journal of Clinical Endocrinology \& Metabolism. 2006; 91: 4287-4294.

24. Deutschländer M, Van de Venter M, Roux S, Louw J \& Lall N. Hypoglycaemic activity of four plant extracts traditionally used in South Africa for diabetes. Journal of Ethnopharmacology. 2009; 124: 619-624.

25. Rössner S, Sjöström L, Noack R, Meinders A \& Noseda G. Weight loss, weight maintenance, and improved cardiovascular risk factors after 2 years treatment with orlistat for obesity. Obesity Research. 2000;8: 49-61. 